\title{
A STUDY OF THE STATUS AND FACTORS AFFECTING ISONIAZIDE CHEMOPROPHYLAXIS FOR PAEDIATRIC CONTACTS OF THE SMEAR POSITIVE TUBERCULOSIS CASES IN EAST DISTRICT OF SIKKIM IN INDIA
}

\author{
Forhad Akhtar Zaman'1, Vijay Kumar Mehta², Utpal Sharma³
}

${ }_{1}^{1}$ Professor, Department of Community Medicine, SMIMS, Gangtok, Sikkim.

2 Professor \& HOD, Department of Community Medicine, SMIMS, Gangtok, Sikkim.

${ }^{3}$ Assistant Professor, Department of Community Medicine, FAAMC, Barpeta, Assam.

\begin{abstract}
BACKGROUND

The state of Sikkim in India is overburdened with Tuberculosis (TB) in general and childhood TB in specific and is having the highest proportion of Multi Drug Resistant (MDR) TB cases in India. Isoniazide preventive therapy (IPT) has been found to be highly effective in preventing latent TB infection in children.
\end{abstract}

\begin{abstract}
MATERIALS AND METHODS
It was a prospective study with universal sampling method conducted amongst all the children under 6 years of age who were household contacts of sputum positive pulmonary TB cases being treated in East Sikkim district in the first two quarters of 2016. Home visits were done to find out the Isoniazid prophylactic therapy status along with factors for the compliance. Eligible children not on IPT were counselled to start Isoniazid (INH) and those who initiated were counselled to complete the entire course of IPT. Home visit were made again at the end of 6 months of initiation of treatment to note their IPT completion status.
\end{abstract}

\section{RESULTS}

Out of the total 30 pediatric household contact, $24(80 \%)$ initiated IPT without any health education intervention. Among those who did not initiate IPT without any health education intervention, 4 out of $5(80 \%)$ of them initiated IPT after the health education intervention showing a positive impact of the health education given to them. Lack of awareness about IPT amongst the parents was the most common reason cited by parents for those who did not initiate IPT. After 6 months of follow up, total 20 (71.4\%) children were found to have completed the IPT. Among the children who did not initially initiate IPT and then started IPT after receiving health education, $75 \%$ of them (3 out of 4 ) were found to have completed IPT.

\section{CONCLUSION}

Health education intervention was found to be an effective tool for compliance of IPT. This study had a huge impact in terms of proving that the integration of preventive therapy for the contacts along with the treatment of the index case can be done with no extra burden and cost in the ongoing National Health Programme for TB.

\section{KEYWORDS}

Isoniazide Prophylaxis Therapy (IPT), Pediatric Contact, Smear Positive Tuberculosis.

HOW TO CITE THIS ARTICLE: Zaman FA, Mehta VK, Sharma U. A study of the status and factors affecting isoniazide chemoprophylaxis for paediatric contacts of the smear positive tuberculosis cases in east district of Sikkim in India. J. Evolution Med. Dent. Sci. 2017;6(77):5486-5492, DOI: 10.14260/Jemds/2017/1191

\section{BACKGROUND}

Tuberculosis (TB) in general \& MDR-TB specifically affects the economically productive age group and has emerged as a significant socio-economic burden in India. Uncountable children in India have to leave school permanently and have to take up jobs in order to supplement the household income because of their parents' tuberculosis, and more women are rejected by their families because of having tuberculosis.[1,2] Nestled in the Himalayas, the small but beautiful north eastern state of Sikkim with a population of 6 lakh, encircled by The Republic of China, Kingdom of Nepal and Bhutan and state of West Bengal, is overburdened with Tuberculosis (TB)

Financial or Other, Competing Interest: Dr. Zaman reports grants from State TB Cell, Govt. of Sikkim under RNTCP, during the conduct of the study.

Submission 14-08-2017, Peer Review 12-09-2017,

Acceptance 19-09-2017, Published 25-09-2017.

Corresponding Author:

Dr. Forhad Akhtar Zaman,

Professor, Department of Community Medicine,

SMIMS, 5th Mile, Tadong,

Gangtok-737102, Sikkim.

E-mail: drforhad@gmail.com

DOI: $10.14260 /$ jemds/2017/1191

\section{(c) $($ ) $\$$}

as evident by the statistics $(275$ cases per $1,00,000$ population), which is higher than the national average of 247 cases per 1,00,000 population.[3] Even after strengthening of infrastructure and man power deployment in all districts under the RNTCP, situation still remains grim. Disease situation has remained almost constant in two successive years, with caseload of 851 patients detected and put on DOTS in 2015 while a total of 487 cases have already been put on DOTS in the first two quarters itself of the year 2016.[3]

Pediatric tuberculosis (i.e., Tuberculosis (TB) among the population aged less than 14 years) has traditionally received a lower priority than adult TB in National TB programmes because it is considered non-infectious, is difficult to diagnose, cases have been thought to be few and it was wrongly assumed that effective control of adult TB and use of BCG by itself could prevent childhood TB. Contrary to traditional National TB programmes, pediatric tuberculosis (i.e., TB among the population aged less than 14 years) has always been accorded high priority by Revised National Tuberculosis Control Programme (RNTCP) since the inception of the programme in our country.

In India, there are about $\sim 400$ million children who constitute about $34 \%$ of the total population [4]. The extent of 
childhood TB in India is unknown due to diagnostic difficulties; it is estimated to be $10.2 \%$ of the total incidence ${ }^{[5]}$ The maximum risk of a child getting $\mathrm{TB}$ is between 1-4 years when there is an increased risk of progression from infection to disease. Globally, about 1 million cases of pediatric TB are estimated to occur every year accounting for $10-15 \%$ of all $\mathrm{TB}$; ${ }^{6]}$ with more than 100,000 estimated deaths every year, it is one of the top 10 causes of childhood mortality. Though MDR-TB and XDR-TB is documented among pediatric age group, there are no estimates of overall burden, chiefly because of diagnostic difficulties and exclusion of children in most of the drug resistance surveys.

The proportion of pediatric TB cases registered under RNTCP has shown an increasing trend, from 5.6\% (59846 cases) in 2005 to $7 \%$ (84064 cases) in 2011.[7] RNTCP in association with Indian Academy of Pediatrics (IAP) has described criteria for suspecting TB among children; has separate algorithms for diagnosing pulmonary $\mathrm{TB}$ and peripheral TB lymphadenitis and a strategy for treatment and monitoring patients who are on treatment. In brief, TB diagnosis is based on clinical features, smear examination of sputum where this is available, positive family history, tuberculin skin testing, chest radiography and histopathological examination as appropriate. As in adults, children with TB are classified, categorised, registered and treated with intermittent short-course chemotherapy (thriceweekly therapy from treatment initiation to completion), given under direct observation of a treatment provider (DOT provider) and the disease status is monitored during the course of treatment. Based on their pre- treatment weight, children are assigned to one of pre-treatment weight bands and are treated with good quality anti-TB drugs through "ready-to-use" patient wise boxes containing the patients' complete course of anti-TB drugs are made available to every registered TB patient according to programme guidelines. India was the first country to introduce pediatric patient-wise boxes.

Children are highly susceptible to tuberculosis; thus, there is need for safe and effective preventive interventions. It is an established fact that a single case of sputum positive TB can infect around 15 persons per year. Besides it has been proved that Isoniazide preventive therapy (IPT), when taken as prescribed is highly effective in preventing latent TB infection from progressing to clinically apparent disease. INH chemoprophylaxis in children under 6 yrs. of age is one of the important programme activity to limit the disease transmission in the community. On analyzing last 10 Central Internal Evaluations conducted in year 2012, it was noted that $35 \%$ of children less than 6 years did not receive chemoprophylaxis. Since the prevalence of the disease in Sikkim is higher than the national average it is imperative to assess the status of chemoprophylaxis in the state.

\section{MATERIALS AND METHODS Outline of the Study}

The present study is a prospective study conducted amongst the under 6 years children contacts of sputum positive TB patients.

Children who are close contacts (i.e., those sharing the same household) were included in the study.

\section{Target Population}

All children under 6 years who are household contacts of smear positive pulmonary $\mathrm{TB}(\mathrm{Sm}+\mathrm{ve} \mathrm{PTB})$ cases being treated under RNTCP in Sikkim.

\section{Study Population}

Universal sampling of all the eligible pediatric contacts of smear positive pulmonary $\mathrm{TB}(\mathrm{Sm}+\mathrm{ve} \mathrm{PTB})$ cases being treated under RNTCP in East Sikkim district in $1^{\text {st }} \& 2^{\text {nd }} Q$ 2016.

\section{Study Period}

June 2016 to February 2017.

\section{Exclusion Criteria}

1) Contacts of MDR-TB 2) Pediatric contacts with active liver diseases or active TB disease.

\section{Study Design}

Community based cross sectional study.

Names and addresses of the $\mathrm{Sm}+\mathrm{ve}$ cases registered in $1^{\text {st }}$ $\& 2^{\text {nd }} Q$ of 2016 was obtained from the DTO office. The participants were visited and enquired about the number of eligible children and their IPT (Isoniazid prophylactic therapy) status. Eligible children not initiated INH prophylaxis were noted and as a public health measure their parents were advised to contact their DOT centre for INH chemoprophylaxis initiation, with an intimation to the DOT provider in local language. Children already initiated were noted and advised to complete the entire course of IPT.

Home visit were made at the end of 6 months of initiation of treatment to note their IPT completion status.

\section{Sources of Data}

Treatment cards of the registered cases of Sm+ve pulmonary TB cases were used. A semi- structured predesigned and pretested questionnaire were used to get information regarding the status of Isoniazide chemoprophylaxis of the contacts.

\section{Study Variables}

The outcomes noted were as whether initiated on IPT, completion status of IPT (Duration of months over which IPT taken and total number of doses taken). Variables affecting prophylactic chemotherapy like demographic factors (child and the index case)- Age, gender, religion, address, number of children in the family and eligible contacts screened symptomatically, knowledge about IPT amongst the parents, educational status of the both parents, annual income ,occupation and type of the family, distance / time from the institution, reasons for not completing/initiating IPT (loss to follow up/ migration, side effects, lack of drugs, medical reasons, developed active disease), fear of toxicity and other variables like awareness of DOTS provider regarding IPT

\section{Analysis of Data}

The data so collected on the various aspects of the study were entered into a spreadsheet programme. Statistical analysis were conducted using SPSS version 20. Data were categorized and presented in proportion. Chi-square test was used for assessing statistical significance of association table. 


\section{Impact and Value}

Tuberculosis control depends on more than just the science of chemotherapy; chemotherapy can be successful only within the framework of the overall clinical and social management of patients and their contacts. Isoniazide prophylaxis therapy (IPT) in contacts would not only improve individual clinical management but would aid to reduce the burden of disease in the community, improve clinical research for the prevention and treatment of the disease, and allow greater scope of diagnostics and case management in RNTCP. The consequences of latent TB amongst the contacts are considerable and may exacerbate rapidly leading to disseminated tuberculosis. Improved screening and IPT amongst the contacts will provide the opportunity to expand on the strategies for infection control of tuberculosis under the RNTCP in the future. Moreover the prospective issue is of the integration of preventive therapy for the contacts along with the treatment of the index case in the ongoing programme. The compliance of the prophylaxis for the contact of TB case treatment could be carried out with same strategy of supervision, infrastructure and manpower as for the TB case under DOTS with no extra burden.

\section{RESULTS}

Out of all the participants in the study, a great majority was (40.9\%) percent of the NSP TB cases in this study were in the age group of 26 to 35 years; little more than one third were in 15-25 age groups; 36.4 percent were from Hindu community. The trend of Tuberculosis was found to be decreasing with increase in age and there was no difference between males and females. Literacy was quite high among the participants; only 4.5 percent was found to be illiterate; 72.8 percent crossed primary school level, 4.5 percent reached college education. Participants from Joint families were less (22.7\%) compared to nuclear and three generation families (77.3\%). Family size of the participants was relatively lower in our study. Family size up to two was not noted; 45.5 percent were from family size six and higher. Overall, 77.77 percent were married; 90.74 percent were above below poverty line (APL); migrant population was 25.92 percent. Very few $(18.18 \%)$ of them were the sole earning member of their family. Majority were unemployed workers (45.5\%) which includes housewives \& students and others were skilled (18.2\%) and unskilled workers $(18.2 \%)$ (Table 1$)$.

Majority of the patients (54.5\%) had clinical symptoms of "cough for more than three weeks with fever" and very few (9.1\%) presented with Fever only. Regarding the history of contact, it was observed that $50 \%$ of the study population had given positive history of the same. A large number of the study population (36.5\%) was found to have habits of both alcohol \& smoking, none declared to be having habits of smokeless Tobacco. Regarding parameters of healthful housing, it was found that $50 \%$ of the houses were pucca, $54.6 \% \& 54.7 \%$ of the houses were not having adequate ventilation \& adequate lighting respectively and $22.7 \%$ of the houses were found to have overcrowding which might have contributed to the causation of Tuberculosis. Indoor air pollution was present in $63 \%$ of the houses.

More than half of the study population (63.5\%) had Sputum examination \& the rest (36.5\%) had X-ray examination as their Initial approach to diagnosis. (Table 2)
Majority of the study population (81.9\%) were motivated for treatment by house-hold members \& the rest $(13.6 \%)$ were motivated by health workers. It was observed that the majority of the study subjects (54.5\%) were brought for treatment within first 3 weeks of the onset of symptom. (Table 3).

Out of the total pediatric household contact, $80 \%$ initiated IPT without any health education intervention.

Among those who did not initiate IPT without any health education intervention, $80 \%$ of them initiated IPT after the health education intervention showing a positive impact of the health education given to them.

Lack of awareness about IPT amongst the parents was the most common reason cited by parents for those who did not initiate IPT.

After 6 months of follow up, 71.4\% children were found to have completed the IPT.

Among the children who did not initially initiate IPT and then started IPT after receiving health education, $75 \%$ of them were found to have completed IPT. (Table 4, 5 \& 6)

There was no statistically significant association between IPT Completion status and Health Education Intervention. (Table 7).

\begin{tabular}{|c|c|c|c|c|c|}
\hline \multicolumn{6}{|c|}{ Age-Sex } \\
\hline \multirow[b]{2}{*}{ Age (Years) } & \multicolumn{2}{|c|}{ Sex } & \multirow[b]{2}{*}{ Total } & \multirow{2}{*}{\multicolumn{2}{|c|}{ Percentage }} \\
\hline & $\begin{array}{c}\text { Male } \\
\text { (\%) }\end{array}$ & $\begin{array}{c}\text { Female } \\
(\%)\end{array}$ & & & \\
\hline $15-25$ & 3 & 5 & 8 & \multicolumn{2}{|c|}{36.4} \\
\hline $26-35$ & 5 & 4 & 9 & \multicolumn{2}{|c|}{40.9} \\
\hline $36-45$ & 1 & 2 & 3 & \multicolumn{2}{|c|}{13.6} \\
\hline $46-55$ & 1 & 1 & 2 & \multicolumn{2}{|c|}{9.1} \\
\hline $56-65$ & & & & \multicolumn{2}{|c|}{0} \\
\hline $66-75$ & & & & \multicolumn{2}{|c|}{0} \\
\hline Total & 10 & 12 & 22 & \multicolumn{2}{|c|}{100} \\
\hline \multicolumn{6}{|c|}{ Religion } \\
\hline Religion & $\begin{array}{c}\text { Male } \\
\text { (\%) }\end{array}$ & \multicolumn{2}{|c|}{$\begin{array}{c}\text { Female } \\
\text { (\%) }\end{array}$} & Total & $\%$ \\
\hline Christian & 1 & \multicolumn{2}{|c|}{6} & 7 & 31.8 \\
\hline Hindus & 6 & \multicolumn{2}{|c|}{2} & 8 & 36.4 \\
\hline Buddhist & 3 & \multicolumn{2}{|c|}{4} & 7 & 31.8 \\
\hline Total & 10 & \multicolumn{2}{|c|}{12} & 22 & 100 \\
\hline \multicolumn{6}{|c|}{ Educational Status } \\
\hline \multirow{2}{*}{$\begin{array}{c}\text { Educational } \\
\text { Status }\end{array}$} & \multicolumn{3}{|c|}{ Sex } & \multirow{2}{*}{ Total } & \multirow{2}{*}{$\%$} \\
\hline & Male & \multicolumn{2}{|c|}{ Female } & & \\
\hline Graduate \& PG & 0 & \multicolumn{2}{|c|}{1} & 1 & 4.5 \\
\hline High School & 3 & \multicolumn{2}{|c|}{1} & 4 & 18.2 \\
\hline Middle School & 3 & \multicolumn{2}{|c|}{5} & 8 & 36.4 \\
\hline Primary School & 4 & 4 & & 8 & 36.4 \\
\hline Illiterate & 0 & 1 & & 1 & 4.5 \\
\hline Total & 10 & 1 & & 22 & 100 \\
\hline & & pes of $\mathbf{F}$ & amily & & \\
\hline Type of Far & nily & Tot & & Perc & age \\
\hline Joint & & 5 & & & \\
\hline Nuclear & & 8 & & & \\
\hline Three Gener & ation & 9 & & & \\
\hline & & Family $S$ & ize & & \\
\hline Family Si & & Tot & & Perc & age \\
\hline $3-5$ & & 12 & & & \\
\hline $6-8$ & & 7 & & & \\
\hline
\end{tabular}




\begin{tabular}{|c|c|c|c|c|}
\hline Above 8 & \multicolumn{2}{|c|}{3} & \multicolumn{2}{|c|}{13.7} \\
\hline \multicolumn{5}{|c|}{ Occupation } \\
\hline \multirow{2}{*}{ Occupation } & \multicolumn{2}{|c|}{ Sex } & \multirow{2}{*}{ Total } & \multirow{2}{*}{$\%$} \\
\hline & Male & Female & & \\
\hline $\begin{array}{c}\text { Professional }+ \\
\text { Semiprofessional } \\
\end{array}$ & 0 & 1 & 1 & 4.5 \\
\hline Business/Shopkeeper & 3 & 0 & 3 & 13.6 \\
\hline Skilled Worker & 4 & 0 & 4 & 18.2 \\
\hline $\begin{array}{c}\text { Unskilled Worker } \\
\text { (Cultivators \& Laborers) }\end{array}$ & 1 & 3 & 4 & 18.2 \\
\hline $\begin{array}{c}\text { Unemployed } \\
\text { (Students \& Housewife) }\end{array}$ & 2 & 8 & 10 & 45.5 \\
\hline Total & 10 & 12 & 22 & 100 \\
\hline \multicolumn{5}{|c|}{ Earning Members of the Family } \\
\hline Patient alone & \multicolumn{4}{|c|}{4} \\
\hline $\begin{array}{l}\text { Member other than the } \\
\text { Patient }\end{array}$ & \multicolumn{4}{|c|}{10} \\
\hline $\begin{array}{l}\text { Others including the } \\
\text { Patient }\end{array}$ & \multicolumn{4}{|c|}{8} \\
\hline $\begin{array}{r}\text { Table 1. Socio- } \\
\text { of the primary } T B\end{array}$ & $\begin{array}{l}\text { lemo } \\
\text { case }\end{array}$ & $\begin{array}{l}\text { aphic } \\
\text { ith ped }\end{array}$ & $\begin{array}{l}\text { ribut } \\
\text { ric ce }\end{array}$ & \\
\hline
\end{tabular}

\begin{tabular}{|c|c|c|c|c|}
\hline \multicolumn{5}{|c|}{ History of Symptoms at the Beginning } \\
\hline \multirow{2}{*}{ Clinical Symptoms } & \multicolumn{2}{|c|}{ Sex } & \multirow{2}{*}{ Total } & \multirow{2}{*}{$\%$} \\
\hline & Male & Female & & \\
\hline $\begin{array}{l}\text { Cough for more than } \\
\text { three Weeks \& Fever }\end{array}$ & 4 & 8 & 12 & 54.5 \\
\hline Fever & 1 & 1 & 2 & 9.1 \\
\hline $\begin{array}{c}\text { Cough \& Fever with } \\
\text { other Symptoms }\end{array}$ & 5 & 3 & 8 & 36.4 \\
\hline
\end{tabular}

\begin{tabular}{|c|c|c|c|c|}
\hline \multicolumn{5}{|c|}{ History of Contact } \\
\hline Known History of Contact & \multicolumn{2}{|c|}{ Total } & \multicolumn{2}{|c|}{ Percentage } \\
\hline Present & \multicolumn{2}{|c|}{11} & \multicolumn{2}{|c|}{50} \\
\hline Absent & \multicolumn{2}{|c|}{11} & \multicolumn{2}{|c|}{50} \\
\hline \multicolumn{5}{|c|}{ Addiction } \\
\hline \multirow{2}{*}{ Addiction } & \multicolumn{2}{|c|}{ Sex } & \multirow{2}{*}{ Total } & \multirow{2}{*}{$\%$} \\
\hline & Male & Female & & \\
\hline Smoking & 1 & 0 & 1 & 4.5 \\
\hline Alcohol & 1 & 0 & 1 & 4.5 \\
\hline Both smoking \& Alcohol & 8 & 0 & 8 & 36.5 \\
\hline Smokeless Tobacco & 0 & 0 & 0 & 0 \\
\hline None declared & 0 & 12 & 12 & 54.5 \\
\hline \multicolumn{5}{|c|}{ Housing } \\
\hline $\begin{array}{c}\text { Parameters of } \\
\text { Healthful Housing }\end{array}$ & Present & $\%$ & Absent & $\%$ \\
\hline Pucca House & 11 & 50 & 11 & 50 \\
\hline Adequate Ventilation & 12 & & 10 & 45.4 \\
\hline Overcrowding & 17 & & 5 & 22.7 \\
\hline $\begin{array}{c}\text { Sanitary method of excreta } \\
\text { disposal }\end{array}$ & 15 & & 7 & 31.8 \\
\hline Separate Kitchen & 18 & & 4 & 18.2 \\
\hline Indoor Air Pollution & 12 & & 10 & 45.4 \\
\hline \multicolumn{5}{|c|}{ Initial approach to diagnosis } \\
\hline Investigations & \multicolumn{2}{|c|}{ Total } & \multicolumn{2}{|c|}{ Percentage } \\
\hline X-Ray Examination & \multicolumn{2}{|c|}{8} & \multicolumn{2}{|c|}{36.5} \\
\hline Sputum Examination & \multicolumn{2}{|c|}{14} & \multicolumn{2}{|c|}{63.5} \\
\hline \multicolumn{5}{|c|}{$\begin{array}{l}\text { Table 2. Distribution of clinico-social pattern of the } \\
\text { primary TB cases with pediatric contacts }\end{array}$} \\
\hline
\end{tabular}

\begin{tabular}{|c|c|c|c|c|}
\hline \multicolumn{5}{|c|}{ Motivation for Taking Treatment } \\
\hline \multicolumn{2}{|c|}{$\begin{array}{l}\text { Who Motivated for } \\
\text { Taking Treatment }\end{array}$} & Total & \multicolumn{2}{|c|}{ Percentage } \\
\hline \multicolumn{2}{|l|}{ Health Worker } & 3 & \multicolumn{2}{|r|}{13.6} \\
\hline \multicolumn{2}{|c|}{ House-hold Member } & 18 & \multicolumn{2}{|r|}{81.9} \\
\hline \multicolumn{2}{|l|}{ Self } & 1 & \multicolumn{2}{|r|}{4.5} \\
\hline \multicolumn{5}{|c|}{$\begin{array}{c}\text { Sex Distribution of the Time Lag } \\
\text { between Onset of Symptoms and Treatment }\end{array}$} \\
\hline \multirow[b]{2}{*}{ Time Lag } & \multicolumn{2}{|c|}{ Sex } & \multirow[b]{2}{*}{ Total } & \multirow[b]{2}{*}{ Percentage } \\
\hline & $\begin{array}{l}\text { Male } \\
(\%)\end{array}$ & $\begin{array}{l}\text { Female } \\
(\%)\end{array}$ & & \\
\hline Within First 3 Weeks & 6 & 6 & 12 & 54.5 \\
\hline $\begin{array}{l}\text { From } 3 \text { Weeks } \\
\text { to } 6 \text { Months }\end{array}$ & 4 & 6 & 10 & 45.6 \\
\hline \multicolumn{5}{|c|}{$\begin{array}{c}\text { Table 3. Distribution of the determinants of the } \\
\text { treatment adherence \& outcome of the primary } \\
\text { TB cases with pediatric contacts }\end{array}$} \\
\hline
\end{tabular}

\begin{tabular}{|c|c|c|}
\hline Prophylaxis Parameter & Yes & No \\
\hline $\begin{array}{l}\text { Awareness of } \\
\text { Parents on IPT }\end{array}$ & 6 & 24 \\
\hline $\begin{array}{l}\text { Screened for } \\
\text { TB } n=30\end{array}$ & 24 & 6 \\
\hline $\begin{array}{l}\text { Suffering from } \\
\text { Active TB }\end{array}$ & 0 & 24 \\
\hline Whether put on DOTS & 0 & 0 \\
\hline $\begin{array}{l}\text { INH Prophylaxis started without any } \\
\text { Health Education Intervention } \mathrm{n}=30\end{array}$ & 24 & 6 \\
\hline $\begin{array}{c}\text { Received Health Education } \\
\text { (Those who did not start IPT) } n=6\end{array}$ & 5 & 1 \\
\hline $\begin{array}{l}\text { INH Prophylaxis started with Health } \\
\text { Education Intervention } n=5\end{array}$ & 4 & 1 \\
\hline $\begin{array}{l}\text { INH Prophylaxis completed (After } 6 \text { months of } \\
\text { follow up of those who had initiated initially } \\
\text { without any health education intervention) } n=24\end{array}$ & 17 & 7 \\
\hline $\begin{array}{c}\text { INH Prophylaxis completed } \\
\text { (After } 6 \text { months of follow up of those who had } \\
\text { started with health education intervention) } n=4\end{array}$ & 3 & 1 \\
\hline $\begin{array}{l}\text { Total who completed IPT (With \& } \\
\text { without Health Education Intervention) } n=28\end{array}$ & 20 & 8 \\
\hline Side Effects of IPT $n=28$ & 8 & 20 \\
\hline \multicolumn{3}{|l|}{ Table 4. Distribution of the profile \& } \\
\hline
\end{tabular}

\begin{tabular}{|c|c|c|}
\hline Reasons & Total & \% \\
\hline $\begin{array}{c}\text { Lack of awareness about IPT } \\
\text { amongst the parents }\end{array}$ & 3 & 50 \\
\hline $\begin{array}{c}\text { Lack of awareness of DOTS } \\
\text { provider regarding IPT }\end{array}$ & 2 & 33.3 \\
\hline Other Reasons (Age > 6 Years) & 1 & 16.7 \\
\hline
\end{tabular}

Table 5. Distribution of the Pediatric contacts as per the reasons for not initiating IPT $(n=6)$

\begin{tabular}{|c|c|c|}
\hline Reasons & Total & \% \\
\hline Lack of awareness/ motivation & 4 & 50 \\
\hline Developed side effects & 3 & 37.5 \\
\hline $\begin{array}{c}\text { Other Reasons (Doctor advised } \\
\text { to stop drugs after 1 month) }\end{array}$ & 1 & 12.5 \\
\hline $\begin{array}{c}\text { Table 6. Distribution of the pediatric contacts } \\
\text { as per the reasons for not completing IPT }(\boldsymbol{n}=\mathbf{8})\end{array}$ \\
\hline
\end{tabular}




\begin{tabular}{|c|c|c|c|c|}
\hline \multirow{2}{*}{$\begin{array}{l}\text { IPT Completion } \\
\text { Status (among } \\
\text { those who had } \\
\text { not Initiated IPT } \\
\text { Initially) }\end{array}$} & \multicolumn{2}{|c|}{$\begin{array}{c}\text { Received } \\
\text { Health } \\
\text { Education }\end{array}$} & & \multirow{2}{*}{\begin{tabular}{|c|}
$\begin{array}{c}\text { Chi } \\
\text { Square } \\
\text { Test }\end{array}$ \\
$\mathrm{P}=0.2733$ \\
Chi
\end{tabular}} \\
\hline & Yes & No & Total & \\
\hline Completed & 3 & 0 & 3 & square= \\
\hline Not Completed & 2 & 1 & 3 & 1.200 \\
\hline Total & 5 & 1 & 6 & $\begin{array}{c}\text { Not } \\
\text { statistically } \\
\text { significant }\end{array}$ \\
\hline $\begin{array}{r}\text { Table } 7 . \\
\text { status with }\end{array}$ & 110 & & $T$ & $\begin{array}{l}\text { on } \\
\text { tion }\end{array}$ \\
\hline
\end{tabular}

\section{DISCUSSION}

The findings of the present study show that 77.3 percent of the study population was within the age group of 15 years to 35 years. The persons of this age group are economically productive age group of the society. Researchers have noted that 64 percent patients were in the economically productive age group (20-50 years) and all the patients were from the lower socio-economic stratum; $45 \%$ were found by them to be manual labourers. ${ }^{[8]}$

Experts in this field have observed that poverty and inequality were very closely linked and there is a great health challenge in poor and socially excluded groups. Moreover the females are more exposed to the Indoor Air Pollution compared to the male due to the use of Biomass fuel in cooking which probably increased the risk of Tuberculosis. Women constitute 70 percent of the world's poor. Globally there are 1.7 times as many male pulmonary TB cases reported annually as female cases. Some evidence suggests that this may be due to inequities in access to care or may reflect underlying epidemiological differences in TB between men and women. ${ }^{[9,10,11]}$

The present study showed that 9.26 percent of the study population was below poverty line (BPL). Though it has been observed that the burden of tuberculosis disproportionately affects the poor, $[12,13,14]$ but this study showed an inverse relationship with poverty. This may be due to the fact that Tuberculosis in Sikkim does not follow the usual causal pattern as seen in other parts of India. There is a genetic factor responsible for the higher proportion of TB cases in general \& Drug resistant TB in particular in Sikkim. Almost 70 per cent of the MDR strains are found as 'Beijing strains and is considered to be more virulent with a higher tendency to develop drug resistance.[7]

The present study showed that $(54.5 \%)$ had clinical symptoms of "cough for more than three weeks" on the other hand very few (9.1\%) presented with Fever only. Studies conducted by NTI, TRC and Uplekar in Pune have shown that more than $80 \%$ of population, afflicted with a cough for three weeks or more, approaches a health facility seeking relief from their symotoms.[15,16,17]

The present study showed that $36.5 \%$ of the study subjects were found to have habits of both alcohol \& smoking and none declared to be having habits of smokeless Tobacco. A study in Maharashtra and Madhya Pradesh, was conducted to assess the health risk of population exposed to biomass fuel, smoking and chewing tobacco, and unsafe water by linking their reported morbidities of asthma, tuberculosis, and jaundice. The result of the study indicated that exposure to cooking smoke increase the risk of asthma and tuberculosis, smoking and chewing tobacco raise the risk of asthma and tuberculosis.[18] C Kolappan and P G Gopi in their study found a positive association between tobacco smoking and pulmonary (bacillary) tuberculosis. The association also shows a strong dose-response relationship.[19]

The present study noted that in kutcha houses and not having adequate ventilation \& adequate lighting with overcrowding might have contributed to the causation of Tuberculosis. Indoor air pollution was present in $63 \%$ of the houses.

Hsien-Ho Lin, Majid Ezzati, Megan Murray in their study noted that there is consistent evidence of association of tobacco smoking with the increased risk of TB. The findings reveal that passive smoking and biomass fuel combustion creating indoor air pollution also increase TB risk especially among those at high risk for exposure to TB.[20]

Mishra V, Retherford RD, Smith KR examined the effects of cooking smoke from biomass fuels on prevalence of Tuberculosis among persons aged 30 years and older in India as a whole, 53 percent of the prevalence of active tuberculosis is attributable to cooking smoke. Persons living in households that primarily use biomass for cooking fuel have a considerably higher prevalence of active tuberculosis than persons living in households that use cleaner fuels. Results of their study strongly suggested that use of biomass fuels for cooking substantially increased the risk of tuberculosis in India.[21]

The present study showed that 50 percent of the study population had known history of contacts of Tuberculosis. Lutong et al. evaluated the contacts of newly diagnosed smear-positive pulmonary TB patients and Tuberculin Skin Test positivity in the healthy control group. They found that $42 \%$ of very close contacts had positive Tuberculin Skin Test, compared to $34 \%$ close contacts and $13 \%$ sporadic contacts and $16 \%$ of a healthy control group in Jinan, China.[22]

Fortunately it was found that more than half of the study population $(63.5 \%)$ had Sputum examination \& the rest (36.5\%) had X-ray examination as their Initial approach to diagnosis which was as per the Revised National Tuberculosis Control Programme (RNTCP).

Regarding IPT among Pediatric contacts of Sputum positive TB cases, very few studies were done worldwide and almost none in India. In a study done in Gambia, similar results were observed. Of the 328 children commenced on IPT, 318 (96.9\%) started within 1 month of the diagnosis of their respective index cases. Eighteen of the 328 children dropped out of IPT, leaving 310 children remaining on prophylaxis at the end of 6 months. There was no difference in the characteristics of those who dropped out and those who completed prophylaxis. A final 255 of the 328 children (77.7\%, 95\% CI 73.2-82.2) completed the 6 months of IPT with good adherence.[23] Similar results were obtained in some other studies done in different parts of the world.[24,25] In a study done in South India, it was observed that none of the screened pediatric contacts were found to be TB diseased which was similar to our study and 97 (84\%) contacts were initiated on IPT and 19 (16\%) contacts were not initiated on IPT due to shortage of INH tablets in peripheral health centers. The reasons for non-evaluation of the remaining eligible children $(n=56,33 \%)$ include no home visit by the health staff in 25 contacts, home visit done but not evaluated in 31 contacts. [26] 


\section{CONCLUSION}

Health education intervention was found to be an effective tool for compliance of IPT. This study had a huge impact in terms of proving that the integration of preventive therapy for the contacts along with the treatment of the index case can be done with no extra burden and cost in the ongoing National Health Programme for TB.

\section{Recommendations}

1. Since low awareness among parents \& even DOTS provider/Health workers was the most common reason for not starting or completing IPT, it is suggested to impart health education intervention to at least the DOTS providers \& Health workers regarding IPT.

2. Close monitoring of the side effects developed during IPT need to be done to increase the adherence of IPT amongst the pediatric contacts.

3. Integration of preventive therapy for the contacts should be done along with the treatment of the index case as it involves no extra burden or cost within the ongoing National Health Programme for TB (RNTCP).

\section{ACKNOWLEDGEMENTS}

The authors greatly acknowledge the State TB Cell, Govt. of Sikkim for the kind cooperation \& financial support under RNTCP Operational Research of State Task Force, Sikkim.

\section{REFERENCES}

[1] Rajeswari R, Balasubramanian R, Muniyandi M, Geetharamani S, Thresa X, Venkatesan P. Socioeconomic impact of tuberculosis on patients and family in India. Int J Tuberc Lung Dis 1999; 3(10): 869-77.

[2] Muniyandi M, Ramchandran R, Balasubramanian $R$, Narayanan PR. Socio-economic dimensions of tuberculosis control: Review of studies over two decades from Tuberculosis Resrachcentre. J Commun Dis 2006; 39(3): 204-15.

[3] TB India 2016, RNTCP, Annual Status Report, Central TB Division, Directorate General of Health Services, MOHFW, Nirman Bhawan, New Delhi-110108.

[4] The Registrar General \& Census Commissioner, India, New Delhi, Ministry of Home Affairs, Government of India; Available from:

http://www.censusindia.gov.in/Census_Data_2001/In dia_at_Glance/broad.aspx.

[5] Nelson LJ, Wells CD. Global epidemiology of childhood tuberculosis. Internat $\mathrm{J}$ Tubercul Lung Dis. 2004;8:636-47.

[6] World Health Organization. Guidance for National Tuberculosis Programmes on the Management of Tuberculosis in Children, Geneva: WHO, 2006.

[7] Central TB Division. Tuberculosis India 2012. Annual Report of the Revised National Tuberculosis Control Programme, Directorate of General Health Services, Ministry of Health and Family Welfare, Government of India; 2012.

[8] Sukumaran P, K.P. Venugopal KP, Manjooran RS. A social study of compliance with DOTS. Ind. J Tub. 2002; 49: 205.
[9] Muniyandi M; Ramachandran R. Socioeconomic inequalities of tuberculosis in India. Expert Opinion on Pharmacotherapy 2008; 9(10): 1623-8.

[10] Hudelson P. (1996). Gender differentials in tuberculosis: the role of socio-economic and cultural factors. Tuber Lung Dis 77(5): 391-400.

[11] Borgdorff M, Nagelkerke N, Dye C, Nunn P. Gender and tuberculosis: a comparison of prevalence surveys with notification data to explore sex differences in case detection." Int J Tuberc Lung Dis 2000; 4(2): 123-32.

[12] Grange JM. The global burden of tuberculosis. In JD Porter \& JM Grange (Eds.), Tuberculosis: An interdisciplinary perspective. Imperial College Press. London, 1999; pp. 3-31.

[13] Davies RPO, Tocque K, Bellies A, Rimmington T, Davies PDO. Historical declines in tuberculosis in England and Wales: improving social conditions or natural selection? Int J Tuberc Lung Dis 1999; 3(12): 1051-4.

[14] Tupasi TE, Radhakrishna S, Quelapio MI, Villa ML, Pascual ML, Rivera AB, et al. Tuberculosis in the urban poor settlements in the Philippines. Int J Tuberc Lung Dis 2000; 4(1):4-11. Comment in: Int J Tuberc Lung Dis 2000; 4(1):2-3 and Int J Tuberc Lung Dis 2000; 4(10): 990.

[15] Narayan R., Thomas S, Kumari SP, Prabhakar S, Ramaprakash AN, Suresh, T, et al. Prevalence of chest symptoms and action taken by symptomatics in a rural community. Ind J Tub 1976; 23:160-8.

[16] Sudha G, Nirup, C, Rajasakthivel M, Sivasusbramanian, SundramV, Bhatt $S$, et al. Factors influencing the care seeking of chest symptomatics: A community-based study involving rural and urban population in Tamilnadu, South India. Trop Med Int Health 2003:8(4):336-41.

[17] Rangan S. User perspective in urban tuberculosis control. In: Chakrabarty AK, Rangan S, Uplekar M. (Eds) Urban Tuberculosis Control: Problems and Prospects. Mumbai, 1995; 97-106.

[18] Arokiasamy P, Karthick K, Pradhan J. Environmental risk factors and prevalence of asthma, tuberculosis and jaundice in India, International Institute for Population Sciences, Deonar, Mumbai, India. India's National Family Health Survey-2 (NFHS, 1998-99).

[19] Kolappan C, Gopi PG. Tobacco smoking and pulmonary tuberculosis. Thorax 2002; 57 (11): 964-6.

[20] Lin HH, Ezzati M, Murray M. Tobacco smoke, indoor air pollution and tuberculosis: a systematic review and meta-analysis. PLoS Med 2007; 4(1): e20. Comment in: PLoS Med 2007; 4(3):e142.

[21] Mishra V, Retherford RD, Smith KR: Effect of cooking smoke on prevalence of Tuberculosis in India: Honolulu, Hawaii, East-West Center, Program on Population, 1997 Oct. 26 p. (East-West Center Working Papers. Population Series No. 92).

[22] Chatterjee P, Benerjee B, Dutta D, Pati RR, Mullick AK. A Comparative Evaluation of Factors and Reasons for Defaulting in Tuberculosis Treatment in the States of West Bengal, Jharkhand and Arunachal Pradesh. Indian J Tuberc 2003; 50: 17-21. 
[23] U. Egere, A. Sillah, T. Togun, S. Kandeh, F. Cole, A. Jallow, A. Able-Thomas, M. Hoelscher, N. Heinrich, P. C. Hill, B. Kampmann. Isoniazid preventive treatment among child contacts of adults with smear-positive tuberculosis in the Gambia. Public Health Action. 2016 Dec 21; 6(4): 226-231.

[24] Mohamed AM. Adherence to and outcome of isoniazid chemoprophylaxis among household contact children of adults having pulmonary tuberculosis in Alexandria, Egypt. J Egypt Public Health Assoc. 2012 Aug; 87 (34):71-8.
[25] Aminzadeh Z, Asl RT. A six months follow-up on children less than 6 years old in contact with smear positive tuberculosis patients, Varamin city, Tehran, Iran. Int J Prev Med. 2011 Apr; 2(2):79-81.

[26] Pothukuchi M, Nagaraja SB, Kelamane S, Satyanarayana S, Shashidhar, Babu S, Dewan P, Wares F. Tuberculosis contact screening and isoniazid preventive therapy in a South Indian district: operational issues for programmatic consideration. PLoS One. 2011; 6(7):e22500. Epub 2011 Jul 22. 